\begin{tabular}{|l|l|l|}
\hline Volume 5, Number 9 & Research Summary for Practice & 31 DECEMBER 2021 \\
\hline
\end{tabular}

\title{
The Impact of War on U.S. Army Leader Self-Development Domain in the Early 21st Century
}

By

Stephen Pomper, University of South Florida

T The research and conclusion described herein suggest the Global War on Terrorism, more specifically, the U.S. Army's efforts in Iraq and Afghanistan, have caused a severely reduced ability to develop current and future officer leaders. This will result in an undesirable leader snowball effect if not recognized, understood, and ultimately redirected.

Historically, the military has risen to many challenges in the relatively short existence of the United States. While most wars started slow and perilous (Heller \&e Stofft, 1986), the results have proven their value, since the country remains. Still, longstanding and newer challenges persist, and no one in the profession-of-arms can ignore the many calls in military professional magazines, in military doctrine, and in online articles for more adaptive, hyper-creative, and critical-thinking leaders (Ryan, 2020, pp. 6-11). Meanwhile, belligerent nation and non-nation state conflicts are making daily headlines-even talk of nuclear "mutually assured destruction" is becoming in vogue again.

Keywords: Adult learning, Self-determination, Self-determination Theory, Self-development, U.S. Army, Leadership, Leadership-development, War 
There is no question that the Army emphasizes leadership: "leaders are the competitive advantage the Army possesses that technology cannot replace nor be substituted by advanced weaponry and platforms" (United States Department of the Army (DA), 2015, p. vi). Given this, the research asked: How have 19 years of war impacted the U.S. Army's leader self-development today; and perhaps more broadly, how could his influence future leaders for many years to come?

This author, a retired Army officer, saw leader self-development changing and wanted to know why. But it is more than this: The world is a dangerous place, and some argue, more complex than ever before. Newer clashes can be found in space, the web, via social influence, in mega-cites, and more recently, via artificial intelligence (Greer, 2018). Is one or more of these a potential Achilles heel for the Nation? Complicating the military landscape for planners are significant changes to the environment, global socio-economic conditions, and ever-increasing competition for natural resources. The recent COVID-19 pandemic is an example of shock planners cannot anticipate in detail. The fragility of nation-states is well documented throughout history, and this alone should keep self-development at the forefront of leaders' minds.

A crucial aspect of Army soldier-leader improvement is the reliance on self-development, which is one of three "domains" that makes up the Army Leader Development Model (ALDM) in Figure 1. The "operational domain" is experience, mentoring, programmed training, and some unsurprisingly productive on-the-job-training. The "institutional domain" is time spent away from practice and work, and mainly in formal educational and structured training scenarios. The third domain, and the subject of the research, is "self-development;" that is largely as it sounds, but it is better known as self-directed or adult learning in academic literature (DA, 2019, pp. 6-1-6-4).

The research used a grounded theory approach. This blended aspects of Corbin and Strauss accepted work, as well as Charmaz's constructionist approach (Corbin \& Strauss, 2008). To gain an appreciation

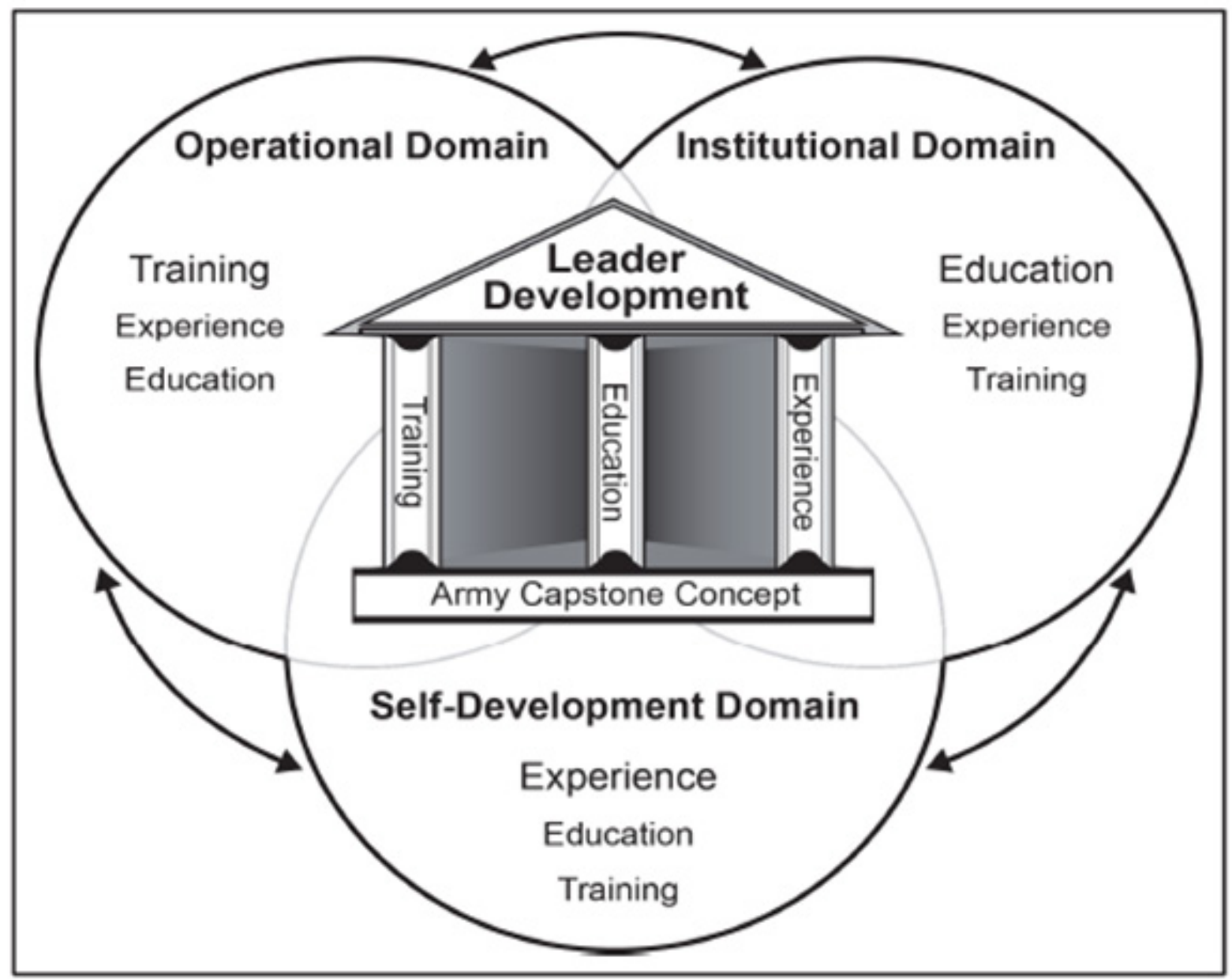

Figure 1. U.S. Army Leader Development Model 
and understanding of the Army's self-development state of affairs, 19 senior officers were interviewed, while their answers to questions were coded and then categorized. The participants were chosen specifically because they had served before the wars and during them. This before and after perspective showed a contrast, as well as some unanticipated results.

\section{Findings}

Army leaders like the bottom line up-front, or BLUF; and its officers can be blunt, without much time needed to think. So, when asked, "Figuratively speaking, do you think the Army's putting its money where its mouth is insofar as self-development?" they did not disappoint. The result was a resounding, "No!" Although a few gave some credit to the Army's many efforts, the largest take-away from the research was that its leaders blamed the organization. This is not consistent with adult learning theories, since the motivation to improve should come from within (albeit with some guidance and mentoring along the way).

A physical finding may actually be the cornerstone of the remaining results. The officer population from 1990 to the start of the wars in 2001, decreased by $27.4 \%$. It then increased by $21.5 \%$ in the next 12 -years. Yet the increase was mostly in junior officers, since you cannot simply inject a seasoned leader, nor can the Army pinch officer-leaders from other armies (like businesses do). That increase was in lieutenants and captains (33\%), but they also make up $60 \%$ of the officer corps. Imagine then, if your organization was $60 \%$ comprised of leaders straight out of college - all in 12-years. Worse for the Army, they rotated these officers to war on two fronts in a 1:1 ratio of deployed to home. But they were not 'home', they were training for their next deployment. If populations were a cornerstone, then the 20-story building was TIME. Self-development requires intrinsic and extrinsic motivation first, but meaningful growth simply takes time. None of these requirements were afforded junior and senior officers during the highest tempo periods of the recent conflicts. The following comments cement the finding: "I've got a working wife and 4 kids, so most of my time is taken up by them;" "[With no time] the first thing that goes overboard is self-development;" "In a unit getting ready to deploy and you're working 16hour days, or 18-hour days or whatever."

For brevity, here are several other findings in shortform:

- Leader's lacked mentors and guides to foster and encourage self-development. This is further described by Brockett and Hiemstra’s (1991) Personal Responsibility Orientation, which describes the importance of "an educational agent" (p. 24) to support adult learning.

- Competition between domains in the ALDM skewed the circles in Figure 1. The operational domain became a beach-ball, the institutional a soccer-ball, while self-development was more like a golf-ball (for some, a marble).

- Those that ascribed to self-development today admitted that they "didn't get it" until around the 10th year of service. For most, this is halfway through a career, and an obvious waste. The next bullet might be why.

- The flip-side to self-development is developing others, and the Army's many regulations clearly put that onus on senior leaders. This is tied to mentoring, but the finding was more nuanced. The research participants rarely described how they developed their subordinates, even after considerable prodding. If one wants to describe their self-development savvy, you would think they would begin by explaining how they inspire others. Perhaps they did not.

\section{Conclusions}

The final analysis did not create a theory, but it paints a picture any army should consider. Sometimes history is all leaders have to guide them, and there is a long history of war, which is costly for any nation and in countless ways. For the U.S. Army, recent conflicts have impacted their leaders in real time and this impact continues to today. The Army has relied on self-development to fill gaps in leadership where structured learning and operations have failed to mitigate the gap. The wars of the early 21st century and this research reflect an uncertain future given the pace of conflicts in the world today.

The self-development domain in the Army is fragmented, but not beyond repair. Although it will take many years since that is the nature of leadership development, some early victories can spark the effort: Learn from sister-services and history; increase military and academic relations; refocus equipment-centric moderation to people-centered; utilize the experience of senior leadership now, before they retire; and finally, simply make time available for leaders to learn.

\section{References}

Brockett, R. G., \& Hiemstra, R. (1991). Self-direction in adult learning: Perspectives on theory, research and practice (Vol. 20). London: Routledge. https://doi.org/10.1177/104515959100200802

Corbin, J., \& Strauss, A. (2008). Basics of qualitative research: Techniques and procedures for developing grounded theory (3rd ed.). Thousand Oaks, CA: Sage Publications, Inc. https://doi. org/10.4135/9781452230153

Greer, J. (2018). Thoughts on military education, 
training and leader development in 2050. Small Wars Journal, Retrieved from http://smallwarsjournal.com/jrnl/art/thoughts-military-education-training-and-leader-development-2050.

Heller, C. E., \& Stofft, W. A. (1986). America's first battles, 1776-1965: University Press of Kansas.

Ryan, M. (2020). The intellectual edge: A competitive advantage for future war and strategic competition. Joint Forces Quarterly, 96 (1st Quarter).

United States Department of the Army (DA). (2015). Leader Development (FM 6-22). Washington,
DC: Headquarters, Department of the Army.

United States Department of the Army (DA). (2019). Army Leadership (ADP 6-22). Washington, DC: Headquarters, Department of the Army.

\section{Review}

This article was accepted under the constructive peer review option. For futher details, see the descriptions at:

http://mumabusinessreview.org/peer-review-options/

\section{Authors}

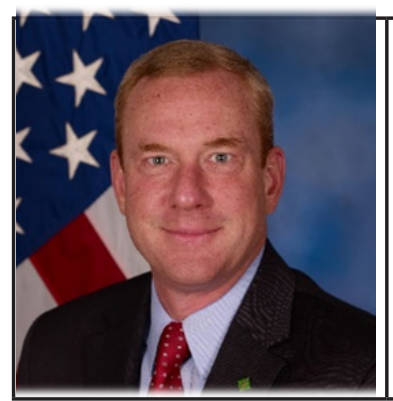

Stephen Pomper is a retired U.S. Army officer, but he has not strayed far from the military in his retirement. He now is a civilian employee working as a senior plans analyst at the Aberdeen Proving Grounds in Maryland. He performs planning to support the Chemical-Biological-Radiological-Nuclear-Explosives operations across the globe. His job requires him to concentrate on programs that coordinate routinely with other federal and local governmental agencies, military combatant commands and other agencies in devising response plans should weapons of mass destruction be deployed. 